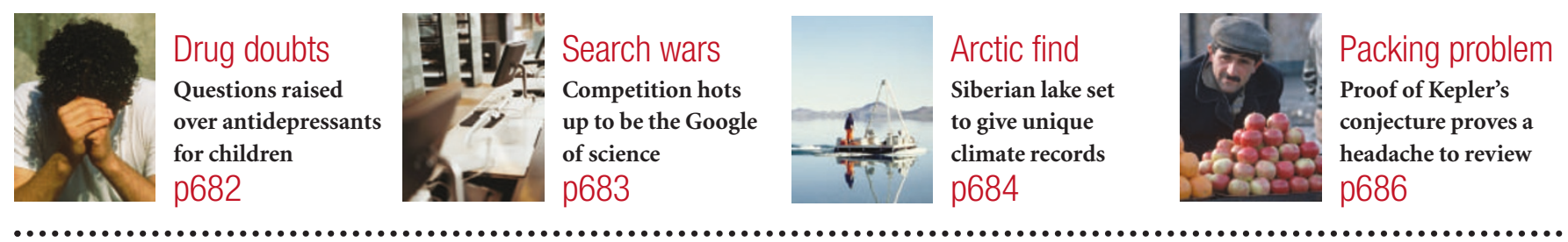

\title{
Push to protect whales leaves seafloor research high and dry
}

Rex Dalton, San Diego

A prestigious US research ship's schedule is in disarray after geophysicists were forced to abandon two recent projects because of concerns that they would harm marine mammals.

The Maurice Ewing - a 2,000tonne vessel operated by LamontDoherty Earth Observatory at Columbia University, New York state - has been docked in Mobile, Alabama, for the past two months after the cruises were blocked.

Conservation officials turned the Ewing away from Bermuda last November and from Mexico in February. A cruise off Venezuela, originally planned for January, has also been delayed for three months, to avoid the seasonal migration of humpback whales there. The Bermudan and Mexican cruises had been planned for several years, involved several institutions and dozens of scientists, and their cost was expected to total about $\$ 2.6$ million.

Researchers on the Ewing use airguns that discharge a sharp burst of compressed air into the ocean to generate sound waves. Geophysicists monitor the reflections from these waves to map rock formations deep under the ocean floor. Marine biologists are becoming increasingly concerned that the use of these devices could harm marine mammals.

In 2000, for example, three beaked whales were found stranded at the Galapagos Islands within $500 \mathrm{~km}$ of a Ewing cruise, and in 2002, two more were discovered during a Ewing project off the west coast of Mexico. Some marine biologists have argued that the strandings are connected with the noise from the devices (see Nature 425, 549; 2003).

The 30-day Bermudan cruise was to study the volcanic rock that supports the islands, and the 40-day cruise off Mexico's Yucatan Peninsula would have looked at the Chicxulub crater, thought to have been formed by the impact of a metorite 65 million years ago.

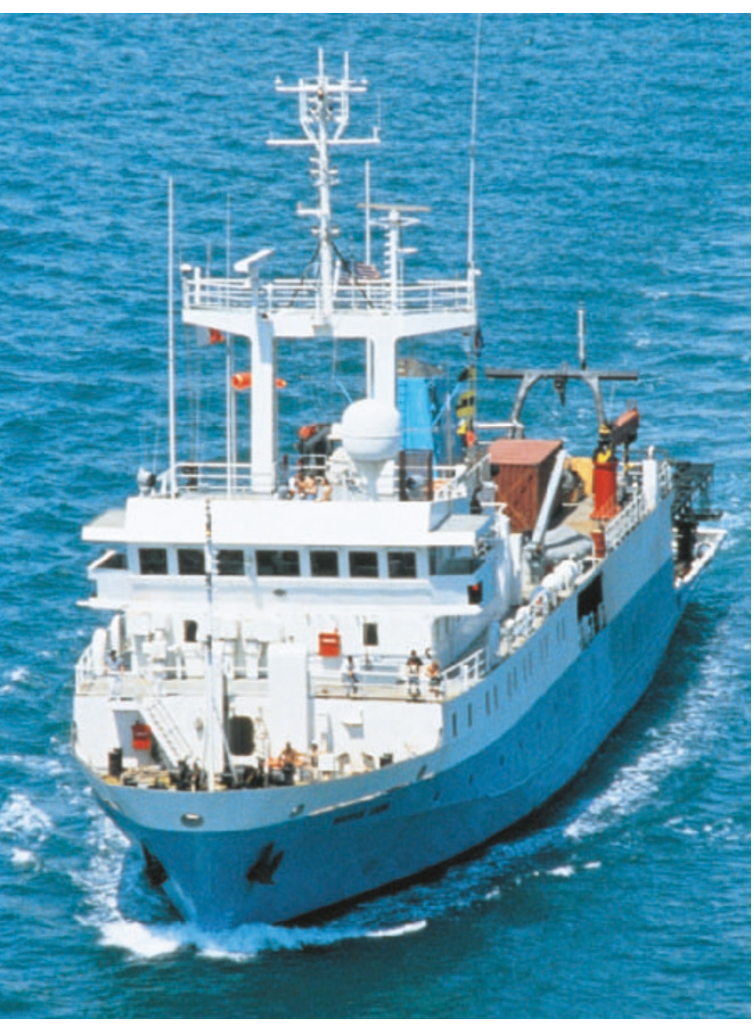

All at sea: whales demolish the Maurice Ewing's cruise schedule.

Ward, director of Bermuda's conservation services. "They didn't give us anything to work with. It is crazy. It was easy to say no." Bermuda's 200-mile territorial ocean zone had been declared a whale sanctuary in July 2000. "They said they wouldn't have come if they'd known that," says Ward.

The researchers debated whether to work from outside Bermuda's territorial waters, before giving up and heading back to port. The trip took a week, with operating costs of $\$ 25,000$ a day. "It was a huge waste of time and money," admits Marcia McNutt, director of the Monterey Bay Aquarium Research Institute in California, and the Bermuda cruise's chief scientist.

But events were repeated on 26 February, when the Ewing arrived at Progresso, Mexico, to study the meteorite crater. Officials at the Secretariat of Environmental and Natural Resources, an environmental agency of the Mexican government, were unconvinced that the cruise would be safe for marine mammals, and ordered the ship to leave Mexican waters. It returned to dock in Mobile.

Sean Gulick, a geophysicist at the

A senior official from the National Science Foundation, which oversees the Maurice Ewing and its work programme, described the cancellations as an "embarrassment", attributable to a lack of proper preparation. "We were not on top of this," says James Yoder, director of ocean sciences at the agency. "We need to review everything we are doing before we leave the dock."

But officials at Lamont-Doherty deny lax planning. "It is unthinkable that we would engage in activities damaging to global ecology," says Michael Purdy, a geophysicist and the institute's director.

Bermuda's environment ministry says that it did not receive an application to approve the cruise until about a month before the ship arrived off the islands on 9 November. Burmudan officials say that applications should be made a year in advance. "The ship showed up without permission," says Jack
University of Texas at Austin and chief scientist on the Mexico cruise, was unavailable for comment. But Paul Stoffa, director of the university's Institute for Geophysics, says that future cruises will have to prepare more carefully. "The mode of operation should be to go through all the steps well in advance," he says.

Another team, which was planning to take the Ewing to Queen Charlotte Sound near Vancouver, Canada, in October, will delay the trip until October 2005 to ensure it has the support and approval of local agencies and populations, says project leader Lincoln Hollister, a geologist at Princeton University.

The actual impact of the experiments on marine life remains uncertain, however. The US Marine Mammal Commission, which is responsible for monitoring marine mammal issues, has formed an advisory committee to assess the problem. 